\title{
EKSPLORASI ETNOMATEMATIKA PADA BUAH NANAS MADU DI DESA BELUK KACAMATAN BELIK KABUPATEN PEMALANG
}

\author{
${ }^{1)}$ Detalia Noriza Munahefi*, ${ }^{2)}$ Dias Indah Melisawati \\ Pendidikan Matematika, Universitas Negeri Semarang, Semarang, Indonesia \\ ${ }^{1)}$ detalia@mail.unnes.ac.id
}

Received:
30/04/2020
Accepted:
07/07/2020
Published:
11/07/2020

\begin{abstract}
This study aims to analyze the cultural elements of honey pineapple which can be applied to mathematics learning. Honey pineapple as one of Pemalang's typical plants, thrives in Beluk Village, Belik District, Pemalang Regency, Central Java. This research method is a qualitative research with ethnographic approach. The ethnographic approach investigates a culture in the environment in the main data collection, observation, and interview. Data analysis in this study consisted of: data reduction, data presentation, descriptive analysis, and drawing conclusions. Utilization of honey pineapple in mathematics learning from the planting process to the process of managing pineapple honey. Application of honey pineapple preparations in mathematics learning starting from the preparation of materials, processing of materials to the presentation of honey pineapple preparations. Mathematical material that can be applied through honey pineapple, among others: arithmetic operations, value comparisons, measurements, building space, and opportunities. The use of pineapple honey in learning ethnomatics nuances is expected to facilitate students' understanding of mathematics learning because the approach is able to present concrete math problems.
\end{abstract}

Keywords: Ethnomatematics, Honey Pineapple, Mathematics Learning

\begin{abstract}
Abstrak
Penelitian ini bertujuan untuk menganalisis unsur-unsur budaya pada nanas madu yang dapat diterapkan pada pembelajaran matematika. Nanas madu sebagai salah satu tanaman khas Pemalang, tumbuh subur di Desa Beluk Kecamatan Belik Kabupaten Pemalang Jawa Tengah. Metode penelitian ini adalah penelitian kualitatif dengan pendekatan etnografi. Pendekatan etnografi menyelidiki suatu kebudayaan di lingkungan dalam pengumpulan data utama, observasi, dan wawancara. Analisis data pada penelitian ini terdiri atas: reduksi data, penyajian data, analisis deskriptif, dan penarikan simpulan. Pemanfaatan nanas madu pada pembelajaran matematika mulai dari proses penanaman sampai dengan proses pengelolahan nanas madu. Pengaplikasian olahan nanas madu pada pembelajaran matematika mulai dari proses penyiapan bahan, pengolahan bahan hingga penyajian olahan nanas madu. Materi matematika yang dapat diaplikasikan melalui nanas madu antara lain: operasi hitung, perbandingan senilai, pengukuran, bangun ruang, dan peluang. Pemanfaatan madu nanas pada pembelajaran bernuansa etnomatematika diharapkan mempermudah pemahaman siswa pada pembelajaran matematika karena pendekatan tersebut mampu menyajikan permasalahan matematika secara konkrit.
\end{abstract}

Kata Kunci: Etnomatematika, Nanas Madu, Pembelajaran Matematika

\section{Pendahuluan}

Matematika merupakan salah satu mata pelajaran wajib di seluruh jenjang sekolah dari mulai sekolah dasar hingga menengah. Konsep-konsep dalam matematika yang disajikan secara abstrak menyebabkan kesulitan pada siswa dalam memecahkan permasalahan. Oleh karena itu perlu adanya suatu pendekatan yang mampu menyajikan permasalahan matematika secara konkrit. Salah satu fungsi matematika menurut Misel (2016) adalah memecahkan masalah yang dihadapi masalah dalam kehidupan seharihari. Kebudayaan yang tumbuh di masyarakat sebagai salah satu penerapan matematika 
pada kehidupan sehari-hari. Hal ini sejalan dengan Mulyo, et al (2018) juga menyatakan bahwa matematika merupakan bagian dari kebudayaan setiap kelompok masyarakat.

Pembelajaran matematika dengan menggunakan pendekatan budaya dikenal dengan istilah etnomatematika. Noto, Firmasari, dan Fatchurrohman (2018), Sirate (2012) penerapan etnomatematika sebagai suatu pendekatan pembelajaran merupakan cara lain untuk menyampaikan matematika secara lebih menarik serta mengatasi kejenuhan. Selain itu etnomatematika juga dapat diartikan sebagai studi tentang hubungan antara matematika dengan latar belakang sosial budaya yang berhubungan yang menunjukkan bagaimana matematika dihasilkan, dialihkan, disebarkan dan dikhususkan dalam sistem budaya yang beragam (Zhang \& Zhang, 2010).

Fajriyah (2018) pembelajaran matematika berbasis budaya merupakan alternatif pembelajaran yang menarik dan inovatif karena mendorong munculnya pemaknaan secara kontekstual berdasarkan pada pengalaman siswa dalam hidup bermasyarakat budaya. Indonesia Negara merupakan negara agraris dimana mayoritas penduduknya berprofesi sebagai petani (Rahmani, et al, 2018). Oleh karena itu salah satu kebudayaan yang dapat diterapkan dalam pembelajaran matematika berupa hasil pertanian dari kabupaten pemalang yakni nanas madu. Nanas madu merupakan salah satu icon Kabupaten Pemalang. Nanas madu memiliki karakteristik yang berbeda dari nanas biasa, yakni rasanya yang lebih manis dan bentuknya yang mungil. Terdapat unsur-unsur matematika pada proses penanaman maupun pengolahan nanas madu tersebut.

Beberapa studi etnomatematika juga mengkaji tentang tanaman maupun makanan khas dari suatu daerah tertentu. Hariastuti (2017) juga menyatakan bahwa potensi local di Banyuwangi berupa buah manggis dapat dimanfaatkan pada pembelajaran matematika dengan mencocokan antara banyak kelopak kulit buah manggis dengan banyak isinya. Mulyo, et al (2018) melakukan penelitian terkait etnomatematika yang muncul mengenai aktivitas dalam bertani jeruk. Ikrimah, Rahmi, dan Darmawan (2017).

Huda (2018) melakukan penelitian bertema etnomatematika dengan memanfaatkan bentuk jajanan pasar di daerah Yogyakarta untuk aplikasi pada geometris serta proses pembuatan dan penjualannya juga ditemukan bentuk model matematika persamaan linear. Makanan khas kota Bengkulu yaitu Bay Tat dimafaatkan oleh Pusvita, Herawati, dan Widada (2019) pada pembelajaran matematika untuk materi perbandingan, perhitungan luas bangun datar, aritmatika sosial, perhitunganperhitungan, dan sebagainya.

Berdasarkan uraian di atas maka nanas madu asal pemalang juga dapat dijadikan subjek dari penelitian dikarenakan adanya unsur matematika dari nanas madu ini sebelum maupun setelah diolah. Oleh karena itu penelitian bertujuan untuk menganalisis unsur-unsur budaya pada nanas madu yang dapat diterapkan pada pembelajaran matematika.

\section{Metode Penelitian}

Penelitian ini dilakukan di Desa Beluk Kecamatan Belik Kabupaten Pemalang Jawa Tengah. Desa tersebut letaknya strategis yaitu di bawah Lereng Gunung Slamet 
sehingga daerah ini memiliki udara yang sejuk dan tanah yang sangat subur. Sebagian besar masyarakat di desa tersebut bermatapencaharian sebagai petani nanas madu.

Penelitian ini merupakan penelitian kualitatif dengan pendekatan etnografi. Pendekatan etnografi menurut Creswell (2012) merupakan salah satu strategi penelitian kualitatif yang menyelidiki suatu kebudayaan di lingkungan dalam pengumpulan data utama, observasi, dan wawancara. Observasi dilakukan untuk mengamati proses penanaman nanas madu serta pengolahan nanas madu menjadi makanan dan minuman. Wawancara dilakukan terhadap petani nanas madu dan produsen pengolah nanas madu.

Langkah selanjutnya setelah data terkumpul adalah analisis data. Analisis data pada penelitian ini terdiri atas: reduksi data, penyajian data, analisis deskriptif, dan penarikan simpulan. Proses analisis data dilakukan secara berurutan dan menyeluruh agar selanjutnya terkumpul data yang disajikan secara terperinci dan dilaporkan secara deskriptif.

\section{Hasil dan Pembahasan}

Pemanfaatan nanas madu pada pembelajaran matematika mulai dari proses penanaman sampai dengan proses pengolahan nanas madu. Aplikasi pembelajaran matematika proses penanaman nanas madu yakni kegiatan petani menanam nanas madu untuk menentukan jumlah pohon nanas madu yang ditanam pada suatu lahan dengan luas tertentu dapat. Berdasarkan hasil wawancara idealnya sebuah nanas madu ditanam pada area berukuran $30 \mathrm{~cm} \times 30 \mathrm{~cm}$. Tabel 1 berikut ini menyajikan perkiraan banyaknya bibit buah nanas madu pada area pertanian yang memiliki luas tertentu.

Tabel 1. Perkiraan Kebutuhan Jumlah Pohon per $m^{2}$

\begin{tabular}{llll}
\hline \hline Petani & Area Tanam & $\begin{array}{l}\text { Luas lahan } \\
\text { ditanami }{ }^{2}\end{array}$ & yang \\
& & Banyaknya bibit \\
\hline Petani 1 & $30 \mathrm{~cm} \times 30 \mathrm{~cm}$ & 900 & 10.000 \\
Petani 2 & $30 \mathrm{~cm} \times 30 \mathrm{~cm}$ & 1080 & 12.000 \\
Petani 3 & $30 \mathrm{~cm} \times 30 \mathrm{~cm}$ & 882 & 9800 \\
\hline
\end{tabular}

Berdasarkan Tabel 1, banyaknya bibit tanaman nanas madu yang dibutuh sebanding dengan luas lahan yang digunakan. Semakin tinggi luas lahannya maka semakin banyak bibit nanas madu yang dibutuhkan. Berdasarkan Tabel 1, banyaknya bibit dapat diperoleh melalui operasi pembagian antara luas lahan yang ditanami dengan luas area tanam tiap nanas madu. Oleh karena itu, pembelajaran matematika yang dapat memanfaatkan kegiatan ini adalah perbandingan senilai dan pembagian bilangan.

Berdasarkan uraian di atas maka kegiatan penanaman nanas madu dapat dijadikan salah satu alternatif dalam kegiatan pembelajaran matematika. Terdapat kerterkaitan konsep matematika pada kegiatan penanaman madu sehingga siswa di daerah sekitar dapat mengaplikasikan secara langsung kegiatan tersebut melalui pembelajaran matematika. Hal ini sejalan dengan Ikrimah, Rahmi, dan Darmawan (2017) yang menyatakan bahwa pada prinsip-prinsip penanaman tersirat adanya konsep matematika. Fadlilah, Trapsilasiswi, dan Oktavianingtyas (2017) juga menyatakan bahwa terdapat aktivitas matematika yang muncul ketika memanen padi yaitu aktivitas 
matematika menghitung dan terdapat konsep perbandingan senilai serta berbalik nilai. Setiawan et al (2019) juga menyatakan bahwa kegiatan bertani dapat diaplikasikan pada pembelajaran matematika melalui kegiatan mengukur, menghitung, dan merancang.

Nanas madu dapat dijadikan sebagai bahan dasar pada makanan maupun minuman yang disajikan pada upacara adat ataupun acara tahunan di Pemalang. Tabel 2 berikut ini menyajikan unsur matematika pada setiap olahan nanas madu di Pemalang.

Tabel 2. Unsur Etnomatematika Pada Olahan Nanas Madu Asal Pemalang

\begin{tabular}{|c|c|c|}
\hline Nanas & ahan dan Cara Pembuatan & ilai Matematika \\
\hline $\begin{array}{l}\text { Dodol nanas } \\
\text { disajikan pada } \\
\text { acara hajatan, } \\
\text { sunnatan, } \\
\text { mantenan, hari } \\
\text { besar islam, } \\
\text { maupun } \\
\text { pengajian. }\end{array}$ & $\begin{array}{l}\text { Bahan terdiri atas: } 1 \text { kg nanas } \\
\text { madu, } 250 \text { ml santan, } 800 \\
\text { gram gula, } 1 \frac{1}{2} \text { ons tepung } \\
\text { ketan, garam secukupnya. } \\
\text { Proses pembuatan sebagai } \\
\text { berikut: } \\
\text { 1. Kupas nanas buang } \\
\text { matanya lalu rendam } \\
\text { dengan garam hingga } 30 \\
\text { menit. } \\
\text { 2. Ditiriskan rendaman } \\
\text { nanas madu tadi } \\
\text { kemudian dicuci dengan } \\
\text { air bersih } \\
\text { Nanas diparut kemudian } \\
\text { dimasak dengan api kecil } \\
\text { 2-3 jam sehingga air } \\
\text { meresap. } \\
\text { 4ngkat dodol nanas yang } \\
\text { sudah matang. }\end{array}$ & $\begin{array}{l}\text { 1. Dodol yang berbentuk } \\
\text { tabung dapat digunakan } \\
\text { sebagai media } \\
\text { pembelajaran geometri } \\
\text { ruang. } \\
\text { 2. Bahan pembuatan dodol } \\
\text { dapat digunakan untuk } \\
\text { penerapan pembelajaran } \\
\text { perbandingan senilai } \\
\text { seperti misalnya } 1 \text { kg } \\
\text { nanas madu } \\
\text { membutuhkan } 800 \text { gram } \\
\text { gula maka } 2 \text { kg nanas } \\
\text { membutuh } 1600 \text { gram } \\
\text { gula. Jadi semakin banyak } \\
\text { nanas madu yang dipakai } \\
\text { semakin bertambah pula } \\
\text { gula yang dipakai. Bahan- } \\
\text { bahan yang lainnya pun } \\
\text { juga dapat digunakan } \\
\text { untuk penerapan } \\
\text { perbandingan. } \\
\text { Satuan pada takaran } \\
\text { bahan seperti kg, gram, dapat } \\
\text { ml, ons dsb debagai } \\
\text { digunakan pembelajaran } \\
\text { penerapan } \\
\text { matematika pada materi } \\
\text { pengukuran. }\end{array}$ \\
\hline $\begin{array}{l}\text { Wajik nanas } \\
\text { disajikan pada } \\
\text { acara Hari besar }\end{array}$ & $\begin{array}{l}\text { Bahan terdiri atas: } 1 \text { nanas } \\
\text { madu, } 250 \text { gram beras ketan, }\end{array}$ & $\begin{array}{l}\text { 1. Bentuk wajik nanas } \\
\text { beragam yaitu bola, limas, } \\
\text { maupun prisma sehingga }\end{array}$ \\
\hline
\end{tabular}




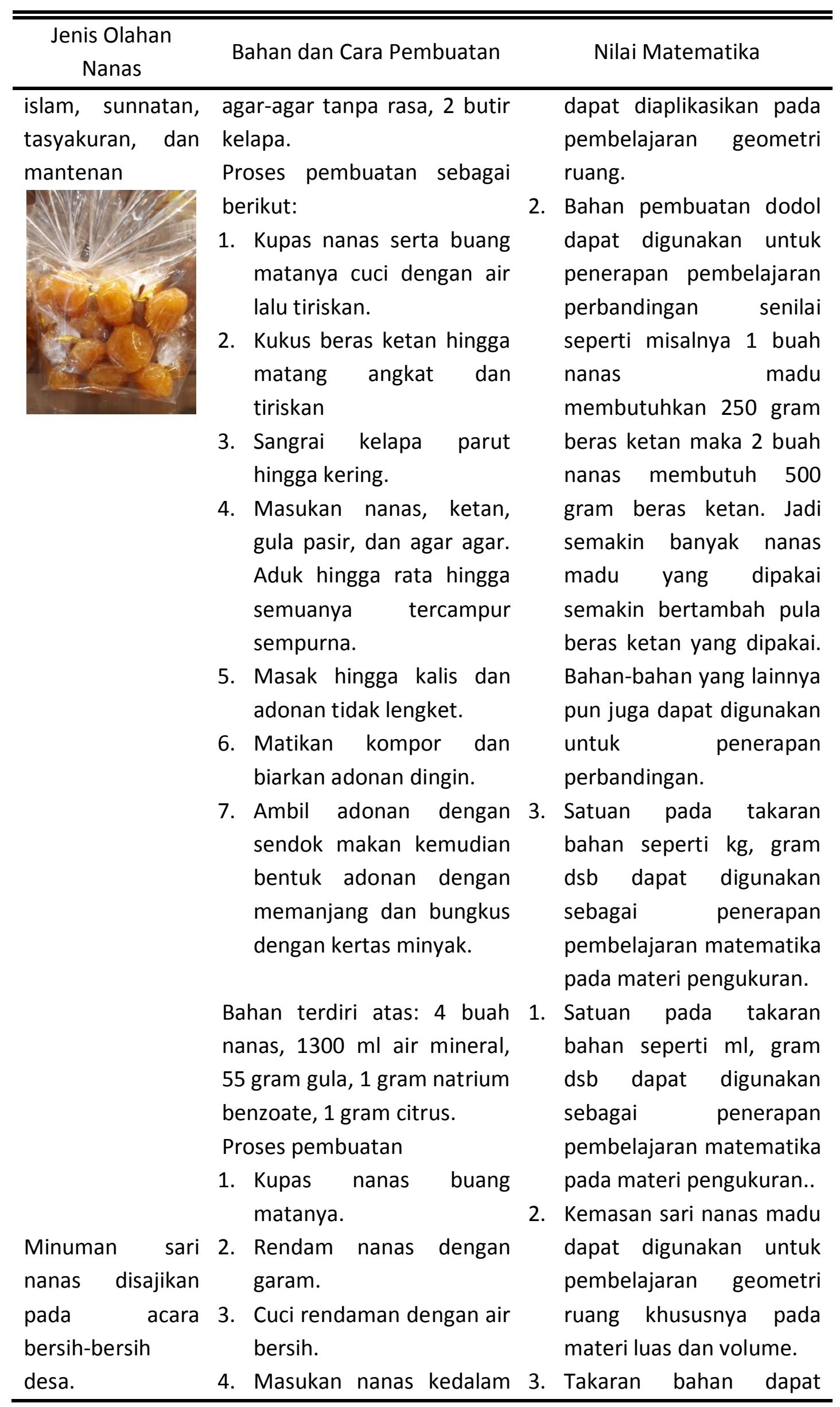




\section{Bahan dan Cara Pembuatan Nilai Matematika}

blender

$\begin{array}{lr}\text { blender } & \text { kemudian } \\ \text { pisahkan sari } & \text { nanas } \\ \text { dengan } & \text { ampas } \\ \text { menggunakan kain saring. }\end{array}$
tunggu hingga mendidih

Selai

nanas

\section{disajikan}

acara lebaran

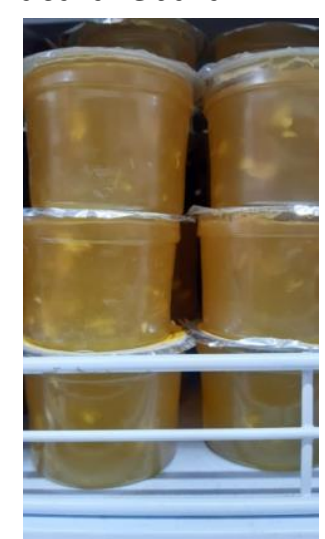

5. Rebus air, tambahkan gula aduk hingga gula terlarut semua dan

6. Masukan sari nanas 250 $\mathrm{ml}$ dan diaduk hingga mendidih.

7. Tambahkan citrus seujung sendok teh dan aduk hingga mendidih terlarut sempurna

8. Matikan kompor dan tunggu hingga dingin

9. Saring menggunakan kain saringan sebanyak 3 kali, bila masih terdapat residu saring kembali.

10. Tambahkan natrium benzoat seujung sendok teh kemudian aduk hingga terlarut sempurna.

11. Kemas minuman dengan gelas plastik.

Bahan terdiri atas: 1 nanas

digunakan untuk

perbandingan senilai.

Semisal perbandingan antara nanas dan air mineral jika pada pembuatan minuman sari nanas madu dibutuhkan 4 buah nanas madu dengan air $1300 \mathrm{ml}$ maka jika air yang tersedia adalah 3900 $\mathrm{ml}$ dibutuhkan sebanyak 8 nanas madu. Jadi semakin banyak air yang dipakai semakin bertambah pula nanas madu yang dipakai. Bahan-bahan yang lainnya pun juga dapat digunakan untuk penerapan perbandingan.

1. Kemasan selai nanas madu dapat digunakan untuk pembelajaran geometri ruang khususnya pada materi volume.

Proses pembuatan terdiri atas:

1. Kupas nanas buang matanya lalu rendam garam hingga 30 menit

2. Ditiriskan rendaman nanas madu tersebut,
2. Takaran bahan bahannya dapat digunakan untuk perbandingan senilai. Semisal perbandingan antara nanas dan gula. Jika pada pembuatan selai nanas madu dibutuhkan 1 


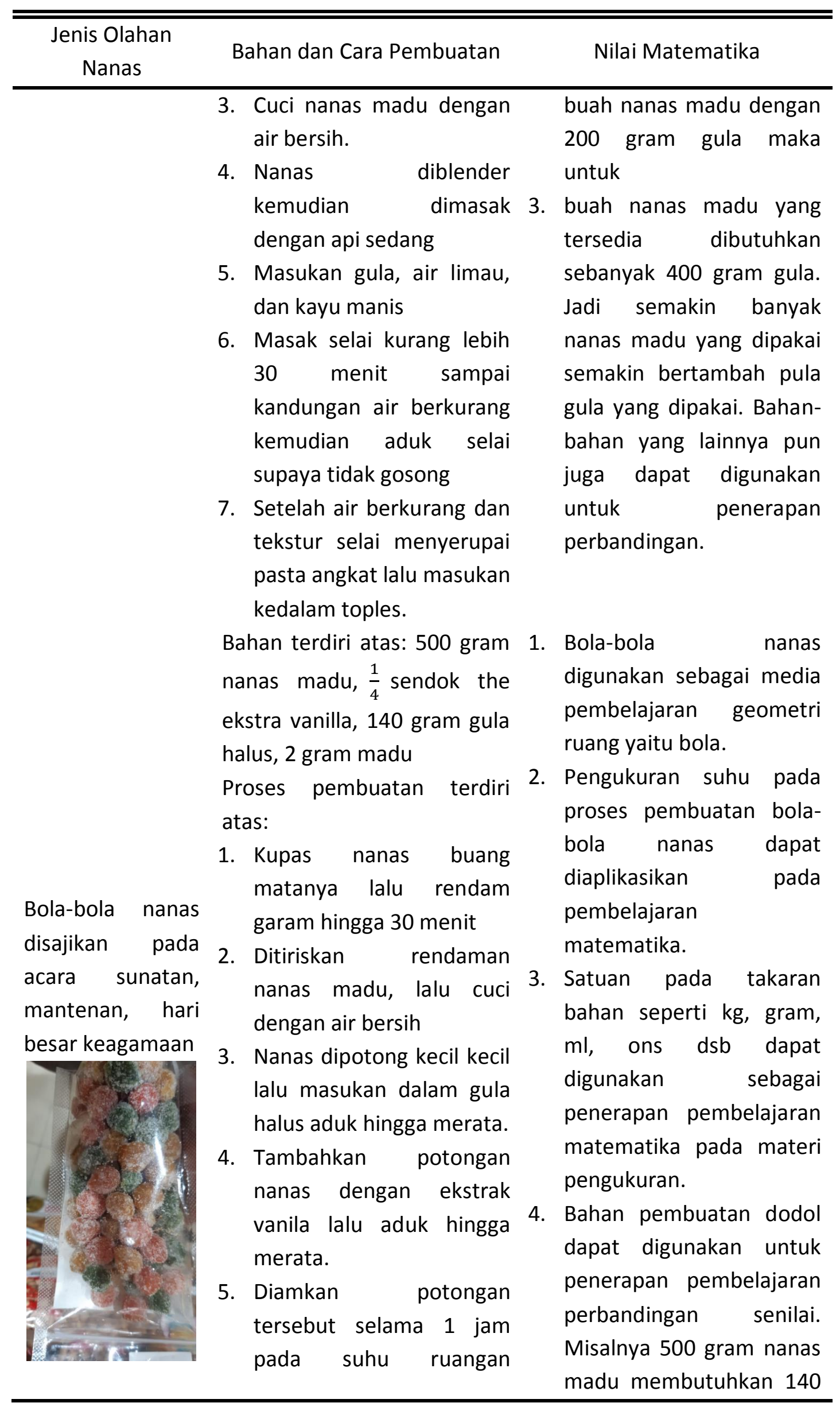




\begin{tabular}{|c|c|c|c|}
\hline $\begin{array}{c}\text { Jenis Olahan } \\
\text { Nanas }\end{array}$ & Bahan dan Cara Pembuatan & & Nilai Matematika \\
\hline & $\begin{array}{l}\text { supaya gula mencair } \\
\text { setelah itu masak hingga } \\
\text { mendidih ganti api } \\
\text { sedang. } \\
\text { 6. Diamkan potongan nanas } \\
\text { hingga } 15 \text { menit sehingga } \\
\text { nanas lengket } \\
\text { 7. Masukan madu lalu } \\
\text { kecilkan lagi apinya } \\
\text { selama } 15 \text { menit. } \\
\text { 8. Tiriskan dalam piring } \\
\text { mulai bentuk permen } \\
\text { sebelum permen } \\
\text { mengeras. }\end{array}$ & 5. & 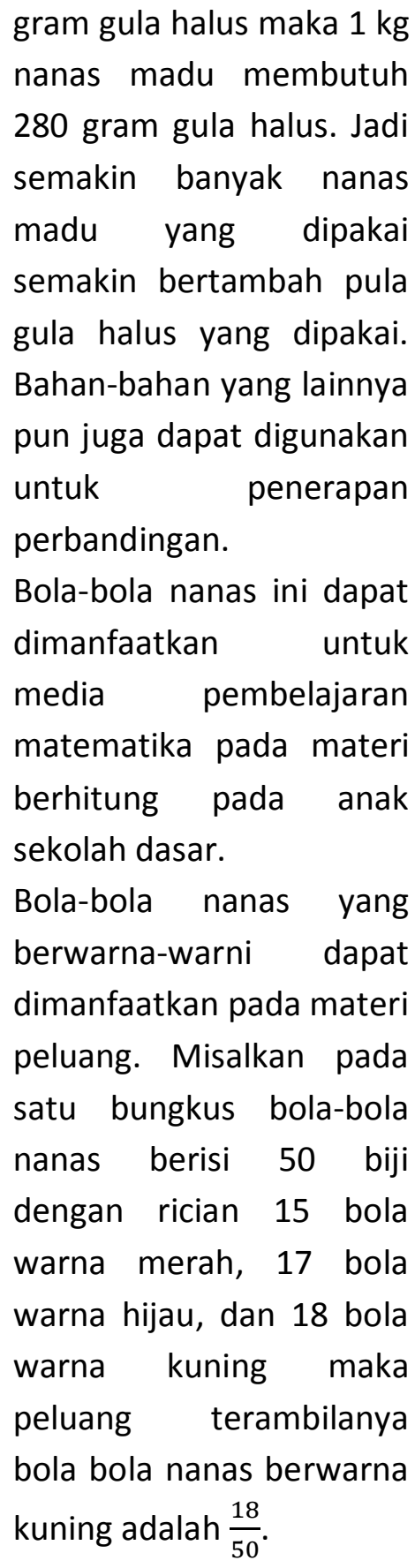 \\
\hline $\begin{array}{l}\text { Krupuk nanas } \\
\text { madu disajikan } \\
\text { pada acara } \\
\text { mantenan, } \\
\text { hajatan, } \\
\text { tasyakuran, hari } \\
\text { besar islam }\end{array}$ & $\begin{array}{l}\text { Bahan yang digunakan terdiri } \\
\text { atas: } 10 \text { biji nanas madu, } 2 \\
\text { butir telur, } \frac{1}{4} \text { gram gula, } 2 \frac{1}{2} \mathrm{~kg} \\
\text { tepung tapioca, } 350 \text { gram } \\
\text { garam } \\
\text { Proses pembuatan terdiri } \\
\text { atas: } \\
\text { 1. Pembuatan }\end{array}$ & 1. & $\begin{array}{l}\text { Adonan krupuk berbentuk } \\
\text { lontong } \\
\text { dimanfaatkan } \\
\text { penerapan } \\
\text { pecahan. } \\
\text { Satuan pada takaran } \\
\text { bahan seperti kg, gram, } \\
\mathrm{ml} \text {, ons dsb dapat }\end{array}$ \\
\hline
\end{tabular}




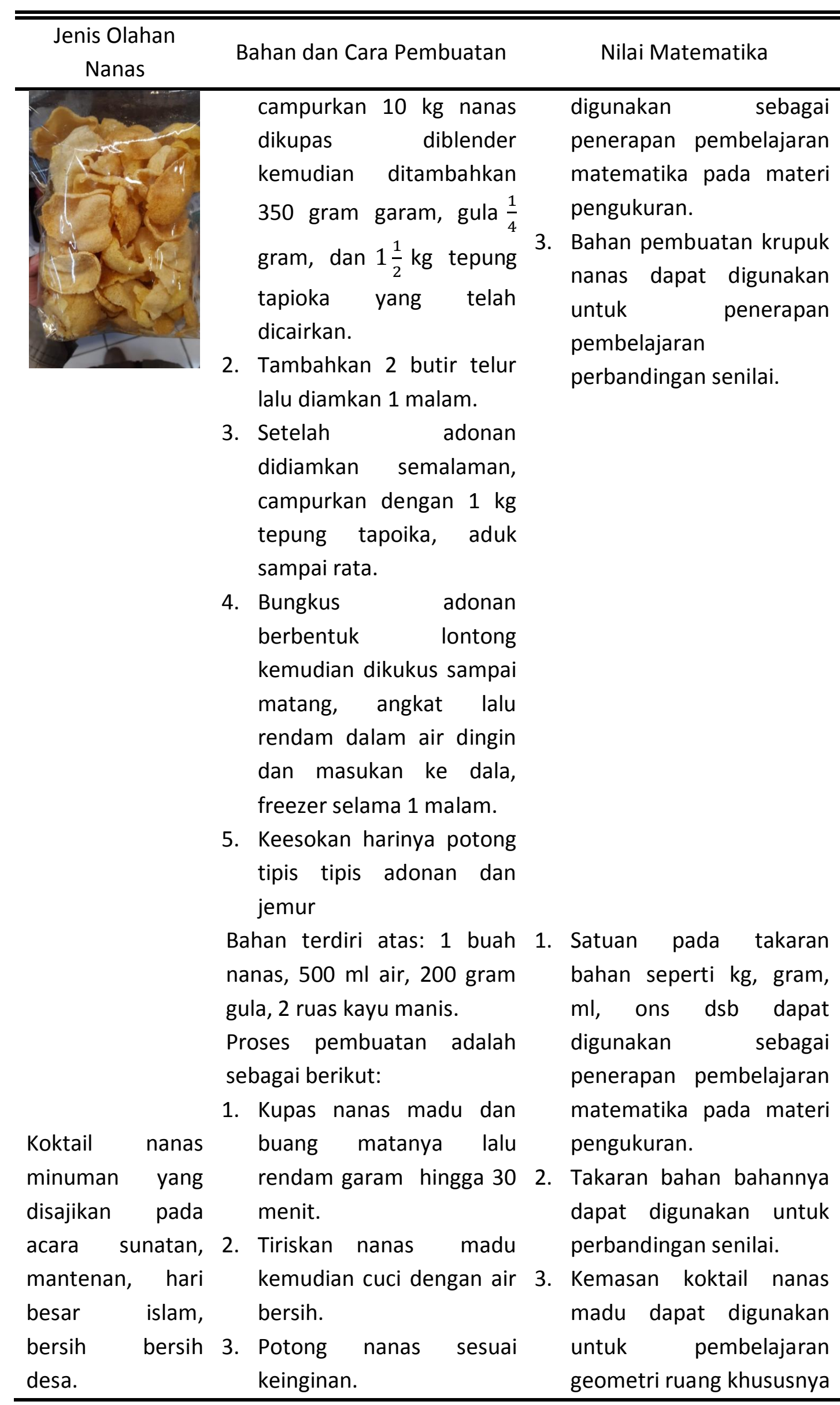




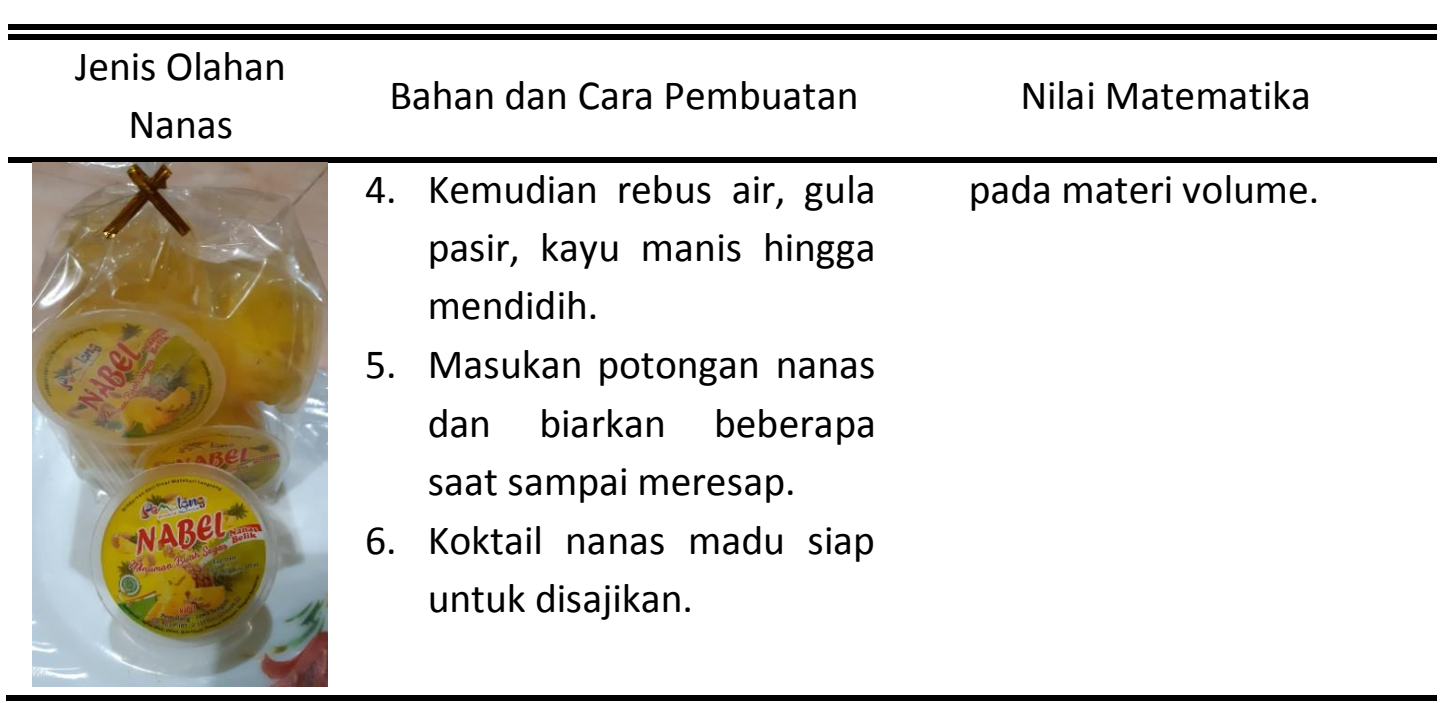

Berdasarkan Tabel 2 diperoleh bahwa hasil olahan nanas madu mulai dari proses penyiapan bahan, pengolahan hingga penyajian dapat diaplikasikan pada pembelajaran matematika. Tabel 2 menampilkan contoh-contoh penerapan olahan nanas madu pada materi berhitung, perbandingan senilai, pengukuran, volume bangun ruang, dan peluang. Berikut ini contoh-contoh penerapan olahan nanas madu pada pembelajaran matematika

1. Penerapan materi berhitung yakni pada suatu kemasan bola-bola nanas terdapat bola nanas dengan warna yang berbeda. Siswa dapat menerapkan operasi hitung dengan menghitung jumlah dari bola nanas pada tiap warna.

2. Bola nanas tersebut juga dapat diaplikasikan pada materi peluang, misalkan siswa dapat menentukan peluang terambilanya bola nanas berwarna merah dari suatu bungkus bola nanas yang terdiri atas warna merah, kuning, dan hijau.

3. Selai nanas, minuman sari nanas, dan koktail nanas dapat diaplikasikan pada materi volume bangun ruang. Kemasan olahan tersebut berbentuk tabung sehingga siswa dapat dengan mengetahui bentuk tabung secara nyata.

4. Pengukuran terdapat pada komposisi dan proses pengolahan nanas madu yang secara rinci dijelaskan dengan menggunakan satuan berat, volume, dan waktu. Pada pembuatan koktail nanas banyaknya gula disebutkan dengan menggunakan satuan berat yaitu gram, air menggunakan satuan volume, yaitu $\mathrm{ml}$, dan proses pembuatan koktail menggunakan satuan waktu yaitu menit.

5. Takaran bahan dapat digunakan untuk perbandingan senilai. Perbandingan antara 1 buah nanas madu membutuhkan 250 gram beras ketan maka 2 buah nanas membutuh 500 gram beras ketan. Jadi semakin banyak nanas madu yang dipakai semakin bertambah pula beras ketan yang dipakai. Bahan-bahan yang lainnya pun juga dapat digunakan untuk penerapan perbandingan.

Materi yang dapat mengaplikasikan dari hasil olahan nanas madu antara lain: berhitung, perbandingan senilai, pengukuran, bangun ruang, peluang, dan lain sebagainya. Oleh karena itu, berdasarkan kegiatan tersebut maka pembelajaran matematika hendaknya dapat dilakukan secara nyata. Hal ini sejalan dengan Laurens, (2010) yang menyatakan bahwa matematika seharusnya dilihat sebagai aktivitas 
manusia. Hal ini menjadikan matematika sebagai mata pelajaran yang menyenangkan karena dapat secara langsung diaplikasikan dalam kehidupan sehari-hari.

\section{Kesimpulan}

Etnomatematika pada nanas madu diperoleh dari proses penanaman hingga pengolahan nanas madu. Pengaplikasian olahan nanas madu pada pembelajaran matematika mulai dari proses penyiapan bahan, pengolahan bahan hingga penyajian olahan nanas madu. Materi matematika yang dapat diaplikasikan melalui nanas madu antara lain: operasi hitung, perbandingan senilai, pengukuran, bangun ruang, dan peluang. Penerapan madu nanas melalui pendekatan etnomatematika diharaphkan mempermudah pemahaman siswa pada pembelajaran matematika khususnya pada materi operasi hitung, perbandingan senilai, pengukuran, bangun ruang, dan peluang.

\section{Pustaka}

Creswell, J. W. (2012). Educational research: planning. Conducting, and Evaluating.

Fadlilah, U., Trapsilasiswi, D., \& Oktavianingtyas, E. (2017). Identifikasi Aktivitas Etnomatematika Petani Padi pada Masyarakat Jawa di Desa Setail. KadikmA, 6(3), 45-56.

Fajriyah, E. (2018). Peran Etnomatematika Terkait Konsep Matematika dalam Mendukung Literasi. In PRISMA, Prosiding Seminar Nasional Matematika (Vol. 1, pp. 114-119).

Hariastuti, R. M. (2017). Permainan tebak-tebak buah manggis: Sebuah inovasi pembelajaran matematika berbasis etnomatematika. JMPM: Jurnal Matematika dan Pendidikan Matematika, 2(1), 25-35.

Huda, N. T. (2018). Etnomatematika Pada Bentuk Jajanan Pasar di Daerah Istimewa Yogyakarta. Jurnal Nasional Pendidikan Matematika, 2(2), 217-232.

Ikrimah, I., Rahmi, M., \& Darmawan, R. N. (2017). Studi Etnomatematika di Kalangan Petani Desa Kelir Kecamatan Kalipuro. Transformasi: Jurnal Pendidikan Matematika dan Matematika, 1(1).

Laurens, Th. (2010) Analisis Karakteristik PMRI dalam Pembelajaran Pengukuran. Buletin Pendidikan matematika, 10(1)

Misel, E. S. (2016). Penerapan Pendekatan Matematika Realistik Untuk Meningkatkan Kemampuan Representasi Matematis Siswa. Metoda Didaktik, 10 (2), 27-36

Mulyo, R. N., Sunardi, S., Monalisa, L. A., Setiawan, T. B., \& Murtikusuma, R. P. (2018). Etnomatematika Pada Aktivitas Petani Jeruk di Kecamatan Pesanggaran Banyuwangi Sebagai Bahan Ajar Siswa. KadikmA, 9(2), 175-184. 
Noto, M. S., Firmasari, S., \& Fatchurrohman, M. (2018). Etnomatematika pada sumur purbakala Desa Kaliwadas Cirebon dan kaitannya dengan pembelajaran matematika di sekolah. Jurnal Riset Pendidikan Matematika, 5(2), 201-210.

Pusvita, Y., Herawati, H., \& Widada, W. (2019). Etnomatematika Kota Bengkulu: Eksplorasi Makanan Khas Kota Bengkulu "Bay Tat" untuk Memahami Pembelajaran Matematika di Sekolah. Jurnal Pendidikan Matematika Raflesia, 4(2), 185-193.

Rahmani, P. A. E., Susanto, S., Monalisa, L. A., Hobri, H., \& Murtikusuma, R. P. (2018). Eksplorasi Etnomatematika Ritual Seblang Olehsari Terhadap Konsep Geometri. KadikmA, 9(2), 108-117.

Setiawan, T. B., Yudianto, E., Sugiarti, T., Ambarwati, R., \& Agustin, M. A. (2019). Ethnomathematics activities of coffee farmers in Sidomulyo jember area as project student sheet. Journal of Physics: Conference Series (Vol. 1321, No. 2, p. 022124). IOP Publishing.

Sirate, F. (2012). Implementasi etnomatematika dalam pembelajaran matematika pada jenjang pendidikan sekolah dasar. Lentera Pendidikan, 15(1), 41-54.

Zhang, W., \& Zhang, Q. (2010). Ethnomathematics and its integration within the mathematics curriculum. Journal of Mathematics Education, 3(1), 151-157. 